\title{
Raw Biogas as Feedstock for the OCM Process
}

\author{
Barbara Michorczyk $^{1, *}$, Jakub Sikora ${ }^{2}$, Bogusława Kordon-Łapczyńska ${ }^{3}$, Dorota Gaweł ${ }^{1,4}$ and Izabela Czekaj ${ }^{1}$ (i)
}

check for

updates

Citation: Michorczyk, B.; Sikora, J.; Kordon-Łapczyńska, B.; Gaweł, D.; Czekaj, I. Raw Biogas as Feedstock for the OCM Process. Catalysts 2022 12, 54. https://doi.org/10.3390/ catal12010054

Academic Editor: Luciana Lisi

Received: 12 December 2021

Accepted: 31 December 2021

Published: 5 January 2022

Publisher's Note: MDPI stays neutral with regard to jurisdictional claims in published maps and institutional affiliations.

Copyright: (C) 2022 by the authors. Licensee MDPI, Basel, Switzerland. This article is an open access article distributed under the terms and conditions of the Creative Commons Attribution (CC BY) license (https:// creativecommons.org/licenses/by/ $4.0 /)$.
1 Department of Organic Chemistry and Technology, Cracow University of Technology, Warszawska 24, 31-155 Cracow, Poland; Dorota.Gawel@ikifp.edu.pl (D.G.); izabela.czekaj@pk.edu.pl (I.C.)

2 Department of Bioprocess Engineering, Energy and Automation, University of Agriculture in Cracow, Balicka 116 B, 30-149 Cracow, Poland; jakub.sikora@urk.edu.pl

3 Department of Mechanical Engineering and Agrophysics, University of Agriculture in Cracow, Balicka 120, 30-149 Cracow, Poland; boguslawa.lapczynska-kordon@urk.edu.pl

4 Jerzy Haber Institute of Catalysis and Surface Chemistry, Polish Academy of Sciences, Niezapominajek 8 , 30-239 Cracow, Poland

* Correspondence: barbara.michorczyk@pk.edu.pl

\begin{abstract}
The paper presents the research results obtained in the process of oxidative coupling of methane, in which unpurified biogas was used as the feedstock. Biogas obtained from two kinds of biomass materials, i.e., plant materials (potato and beet pulp, Corn-Cob-Mix-biogas 1) and animal waste (waste from fish filleting - biogas 2) was considered. The influence of temperature, the ratio of methane/oxygen and total flows of feedstock on the catalytic performance in oxidative coupling of methane process was investigated. Comparative tests were carried out using pure methane and a mixture of methane-carbon dioxide to simulate the composition of biogas 2 . The process was carried out in the presence of an $\mathrm{Mn}-\mathrm{Na}_{2} \mathrm{WO}_{4} / \mathrm{SiO}_{2}$ catalyst. Fresh and used catalysts were characterised by means of powder $\mathrm{X}$-ray diffraction, $\mathrm{X}$-ray photoelectron spectroscopy, and low-temperature nitrogen adsorption techniques. In oxidative coupling of methane, the type of raw material used as the source of methane has a small effect on methane conversion (the differences in methane conversion are below $3 \%$ ), but a significant effect on the selectivity to $\mathrm{C}_{2}$. Depending on the type of raw material, the differences in selectivity to $\mathrm{C}_{2}$ reach as high as $9 \%$. However, the $\mathrm{Mn}-\mathrm{Na}_{2} \mathrm{WO}_{4} / \mathrm{SiO}_{2}$ catalyst operated steadily in the tested period of time at any feedstock composition. Moreover, it was found that $\mathrm{CO}_{2}$, which is the second main component of biogas in addition to methane, has an effect on catalytic performance. Comparative results of catalytic tests indicate that the $\mathrm{CO}_{2}$ effect varies with temperature. Below $1073 \mathrm{~K}, \mathrm{CO}_{2}$ exerts a small poisoning effect on methane conversion, while above this temperature the negative effect of $\mathrm{CO}_{2}$ disappears. In the case of selectivity to $\mathrm{C}_{2+}$, the negative effect of $\mathrm{CO}_{2}$ was observed only at $1023 \mathrm{~K}$. At higher temperatures, $\mathrm{CO}_{2}$ enhances selectivity to $\mathrm{C}_{2+}$. The effect of $\mathrm{CO}_{2}$ was established by correlating the catalytic results with the temperature programmed desorption of $\mathrm{CO}_{2}$ investigation. The poisoning effect of $\mathrm{CO}_{2}$ was connected with the formation of surface $\mathrm{Na}_{2} \mathrm{CO}_{3}$, whose concentration depends on temperature.
\end{abstract}

Keywords: biogas; $\mathrm{OCM}$; oxidative coupling of methane; $\mathrm{Na}_{2} \mathrm{WO}_{4} / \mathrm{Mn} / \mathrm{SiO}_{2}$ catalyst; methane; biomass

\section{Introduction}

The oxidative coupling of methane has been extensively studied for over 30 years, but the feedstock was usually pure methane; meanwhile, one of the important sources of methane is biogas. Biogas is produced by microorganisms in anaerobic conditions from organic matter. To produce biogas, different organic feedstocks such as municipal, industrial, agricultural waste, waste from slaughterhouses, food waste products, and energy crops can be used [1-6]. It was recently demonstrated that industrial fish processing waste can be efficiently converted to methane in a mono-digestion process [7]. Biochemical potential methane of fish waste was $540.5 \mathrm{~mL} / \mathrm{g}_{\mathrm{VS}}$ (vs-volatile solids) [7], whereas the potential of methane production from waste activated sludge (WAS), depending on the 
organic co-substrates (agricultural, industrial, municipal) used, were in the range of 90 $1480 \mathrm{mLCH}_{4} / \mathrm{g}_{\text {VSadded }}$ [6]. Optimization of methane fermentation process of food waste products made it possible to obtain the biogas in an amount $740.4 \mathrm{~cm}^{3} \cdot \mathrm{g}_{\mathrm{ODM}}{ }^{-1}(\mathrm{ODM}-$ Organic Dry Matter) with $68.6 \%$ methane, at the substrates mixture containing $50 \%$ of meat, $40 \%$ dairy products, $10 \%$ fruit and vegetables [2]. Unfortunately, the use of biogas directly as a feedstock for synthesis is difficult due to its varied composition and the presence of impurities. The biogas yield and composition are influenced by the temperature, $\mathrm{pH}$, type of feedstock, organic loading rate, hydraulic retention time, $\mathrm{C} / \mathrm{N}$ (carbon/nitrogen) ratio, the presence of pollutants such as heavy metals compounds, digester type and pretreatment method [1-10]. Typically, in addition to methane, biogas contains $20-50 \%$ of $\mathrm{CO}_{2}$ and other trace compounds such as $\mathrm{H}_{2} \mathrm{~S}, \mathrm{NH}_{3}$, siloxanes, chlorines, $\mathrm{H}_{2}$ and $\mathrm{O}_{2}$, various volatile organic compounds (VOCs) $[8,9,11] . \mathrm{H}_{2} \mathrm{~S}$ and other sulfur compounds are abundant in agricultural biogas, while silicon compounds are found in low or undetectable amounts [10]. The high amounts of halogenated and organic silicon compounds in landfill biogas is largely the result from industrial waste [8]. The concentrations of VOCs can be high in biogas, especially if they came from organic materials with compounds originating from the biological degradation process, like aromatics and terpenes [8].

Biogas, after cleaning and upgrading, is currently used primarily for the production of electricity/heat, steam; it can also be used as engine fuel, or injected into the gas network. However, recently there has been a growing interest in the possibility of using biogas as a raw material for syntheses. Previous research with the use of biogas included, among others: the process of methanation of carbon dioxide contained in biogas enriched with hydrogen [12-14], co-production of methane and urea (bio methane-urea co-production) [15], conversion of biogas to: syngas, "bio hydrogen" [16-30], or liquid fuels as a result of the contact of biogas with the fraction of liquid crude oil containing a catalyst [31]. The possibility of direct conversion of biogas to methanol is also investigated with the use of methanotrophs-aerobic bacteria capable of using both methane and carbon dioxide as a carbon source for methanol synthesis [32-34]. The attractiveness of this type of solution is related to, inter alia, the possibility of using purified or untreated biogas [32], while in the case of catalytic processes, deep cleaning is usually necessary to remove impurities causing deactivation of the catalyst. Although biogas can be purified and upgraded so that the purity of methane is $>97 \%$, it is an expensive process [35-37]. The cleaning and upgrading methods, as well as the methods of biogas utilisation, have been described in many reviews [38-46]. In recent years some attention has also been paid to techno-economic analyses of the OCM process in order to assess the suitability of biogas as a feedstock for the OCM process $[47,48]$. The conducted analyses show that biogas, as a cheap and easily available raw material, can be an important source of methane for the OCM process. One of the proposed solutions with the use of biogas is to increase its calorific value as a result of its conversion in the OCM process [49,50].

Up to know many studies concerning the application of pure methane and different mixtures of gases with simulated biogas are investigated in OCM process [49-55]. In the tests carried out with the use of pure methane and the mixture $\mathrm{CH}_{4}+\mathrm{H}_{2} \mathrm{~S}+\mathrm{O}_{2}+\mathrm{N}_{2}$ $+\mathrm{CO}_{2}$ as a feed stream, under OCM process conditions, the $\mathrm{Mn}-\mathrm{Na}_{2} \mathrm{WO}_{4} / \mathrm{SiO}_{2}$ catalyst worked stably during $100 \mathrm{~h}$ of tests [49,51]. The presence of various pollutants present in biogas may have both a positive and negative impact on the OCM process and the stability of the catalyst operation. Trace amounts of chlorine derivatives (compounds potentially present in biogas) have a positive effect on the selectivity to $\mathrm{C}_{2}$ and ethylene/ethane molar ratio [52]. The addition of steam to the stream of reactants, when the $\mathrm{Mn}-\mathrm{Na}_{2} \mathrm{WO}_{4} / \mathrm{SiO}_{2}$ catalyst was used, also had a beneficial effect on the OCM process [50,52-54], especially when $\mathrm{H}_{2} \mathrm{O}$ was added at the beginning of the process [53,54]. On the other hand, the presence of $\mathrm{H}_{2} \mathrm{~S}$ in the stream of reactants reduces the methane conversion and selectivity to $\mathrm{C}_{2}$, but the deactivation of the catalyst is significantly influenced by the concentration of $\mathrm{H}_{2} \mathrm{~S}, \mathrm{O}_{2}$ and the temperature at which the process is carried out. [27,49]. Carbon dioxide occupies a special place among the components of biogas, because its contribution to biogas 
can be over $50 \%$ in volume. Research shows that the presence of carbon dioxide in the feed stream plays an important role in the OCM process, and the effect of its presence depends mainly on the process conditions (temperature and the methane/oxygen molar ratio), its concentration in the stream, and the type of catalyst $[52,55]$. However, the use of raw unpurified biogas as a feedstock without purification has not been a subject of research so far.

This paper presents the results of tests in which two types of crude unpurified biogas were used as the feedstock in the OCM process carried out in the presence of the $2 \mathrm{Mn} 5 \mathrm{Na}_{2} \mathrm{WO}_{4} / \mathrm{SiO}_{2}$ catalyst. Biogas was obtained from plant biomass (including the most popular substrate in the world for biogas plants, which is corn silage) and animal waste. Biomass from animal waste is difficult to manage but, as shown by recent studies, it has a high potential for methane production in the mono-digestion process [7]. These two types of biogas were selected in order to compare the properties of biogas obtained from plant biomass and animal waste in terms of their use as a source of methane for the OCM process. The obtained results were compared with those obtained for pure methane and for a mixture simulating the composition of biogas 2 , i.e., containing methane and carbon dioxide in the same volume ratios as in biogas 2 .

\section{Results and Discussion}

\subsection{Physicochemical Characterization}

The low temperature $\mathrm{N}_{2}$ adsorption data for the multicomponent $\mathrm{Mn}-\mathrm{Na}_{2} \mathrm{WO}_{4} / \mathrm{SiO}_{2}$ catalyst before and after the catalytic reaction are summarized in Table 1 . The data for individual $\mathrm{SiO}_{2}, \mathrm{Mn} / \mathrm{SiO}_{2}$, and $\mathrm{Na}_{2} \mathrm{WO}_{4} / \mathrm{SiO}_{2}$ components are provided as reference. The analysis of low temperature $\mathrm{N}_{2}$ adsorption isotherms reveals that the deposition of manganese on silica support has only a small influence on the total pore volume $\left(\mathrm{V}_{\text {total }}\right)$ and specific surface area $\left(\mathrm{S}_{\mathrm{BET}}\right)$, while the deposition of the $\mathrm{Na}_{2} \mathrm{WO}_{4}$ phase leads to the destruction of a porous structure of the support. These dramatic changes in $S_{B E T}$ and $\mathrm{V}_{\text {total }}$ are due to the phase transformation of amorphous silica into crystalline $\alpha$-cristobalite occurring in the thermal treatment of the catalysts. It has been found that such phase transformation of amorphous silica to either $\alpha$-cristobalite or quartz is facilitated by sodium cations [56,57] originating, in our case, from $\mathrm{Na}_{2} \mathrm{WO}_{4}$. Amorphous silica transforms into $\alpha$-cristobalite in the temperature range 1743-1973 K [56-58]. However, it was found that in the presence of sodium ions, the transformation of silica into $\alpha$-cristobalite is possible already in the temperature range of 1023-1123 K [56,57,59,60]. Low-temperature $\mathrm{SiO}_{2}$ transformation to cristobalite was also observed in the case of the $\mathrm{Na} / \mathrm{SiO} 2$ and $\mathrm{Na}_{2} \mathrm{WO}_{4} / \mathrm{SiO}_{2}$ catalysts $[57,61]$. It was also found that the presence of sodium in the form of $\mathrm{NaOH}$ leads to crystallization only at $1173 \mathrm{~K}$, and the $\alpha$-cristobalite phase is accompanied by the $\alpha$-tridimite phase (at $1023 \mathrm{~K}$, only the amorphous phase is present) [57]. In the samples containing no sodium ions, but containing manganese or tungsten ions, the low-temperature transformation of silica to $\alpha$-cristobalite did not occur. The presence of crystalline $\alpha$-cristobalite in all the samples containing $\mathrm{Na}_{2} \mathrm{WO}_{4}$ is confirmed with XRD (Figure 1). For all of those samples, reflections characteristic of the crystal phases of quartz and $\mathrm{Na}_{2} \mathrm{WO}_{4}$ were present simultaneously. The intensity of reflections due to quartz increases after the OCM reaction, regardless of the presence of $\mathrm{CO}_{2}$, which suggests a further phase transformation during the process. 
Table 1. Porosity and phase composition of fresh and used catalysts ${ }^{\text {a }}$.

\begin{tabular}{ccc}
\hline Sample & $\begin{array}{c}\mathbf{S}_{\text {BET }} \\
\left(\mathbf{m}^{\mathbf{2}} \mathbf{g}\right.\end{array}$ & $\begin{array}{c}\mathbf{V}_{\text {Total }} \\
\left(\mathbf{c m}^{\mathbf{3}} \mathbf{g}^{-\mathbf{1}}\right)\end{array}$ \\
\hline $\mathrm{SiO}_{2}$ & 474 & 0.83 \\
\hline $\mathrm{Mn} / \mathrm{SiO}_{2}$ & 427 & 0.78 \\
\hline $\mathrm{Na}_{2} \mathrm{WO}_{4} / \mathrm{SiO}_{2}$ & 2.1 & $<0.01$ \\
\hline $\mathrm{Mn}-\mathrm{Na}_{2} \mathrm{WO}_{4} / \mathrm{SiO}_{2}$ & 1.9 & $<0.01$ \\
\hline $\mathrm{Mn}-\mathrm{Na}_{2} \mathrm{WO}_{4} / \mathrm{SiO}_{2}{ }^{\mathrm{a}}$ & 1.9 & $<0.01$ \\
\hline $\mathrm{Mn}-\mathrm{Na}_{2} \mathrm{WO}_{4} / \mathrm{SiO}_{2}{ }^{\mathrm{b}}$ & 2.0 & $<0.01$ \\
\hline $\mathrm{Mn}-\mathrm{Na}_{2} \mathrm{WO}_{4} / \mathrm{SiO}_{2}{ }^{\mathrm{c}}$ & 1.9 & $<0.01$ \\
\hline $\mathrm{Mn}-\mathrm{Na}_{2} \mathrm{WO}_{4} / \mathrm{SiO}_{2}{ }^{\mathrm{d}}$ & 1.9 & $<0.01$ \\
\hline
\end{tabular}

a Used sample after process with mixture of $\mathrm{CH}_{4}+\mathrm{O}_{2}+\mathrm{He}$ (for all used catalysts the reaction conditions in caption to Figure 1). ${ }^{\mathrm{b}}$ Used sample after process with mixture of $\mathrm{CH}_{4}+\mathrm{CO}_{2}+\mathrm{O}_{2}+\mathrm{He} .{ }^{\mathrm{c}}$ Used sample after process with mixture of biogas $1+\mathrm{O}_{2}+\mathrm{He} .{ }^{\mathrm{d}}$ Used sample after process with mixture of biogas $2+\mathrm{O}_{2}+\mathrm{He}$

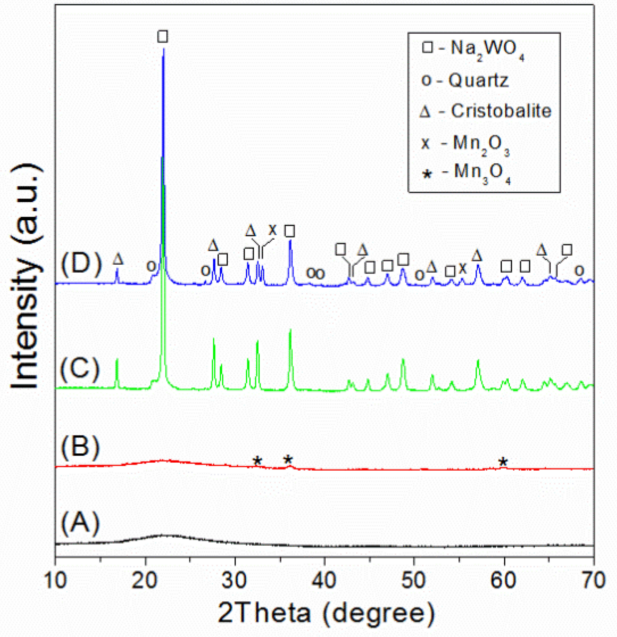

(a)

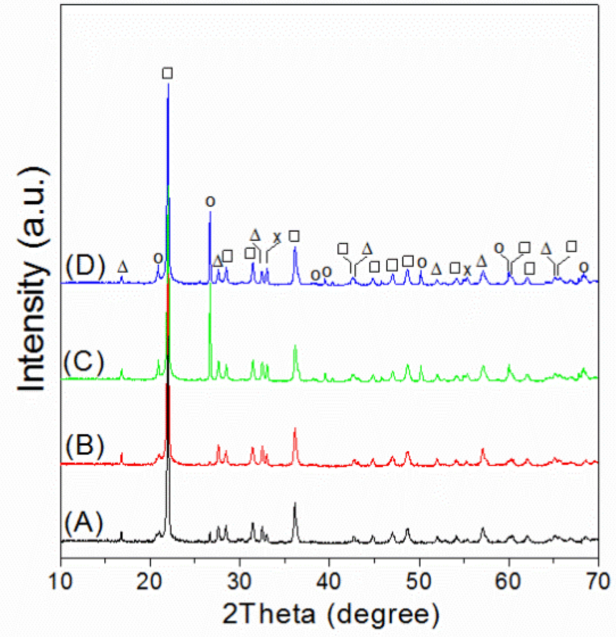

(b)

Figure 1. XRD patterns of (a) fresh (A) $\mathrm{SiO}_{2}$, (B) $\mathrm{Mn} / \mathrm{SiO}_{2}$, (C) $\mathrm{Na}_{2} \mathrm{WO}_{4} / \mathrm{SiO}_{2}$ and (D) Mn$\mathrm{Na}_{2} \mathrm{WO}_{4} / \mathrm{SiO}_{2}$ samples and (b) $\mathrm{Mn}-\mathrm{Na}_{2} \mathrm{WO}_{4} / \mathrm{SiO}_{2}$ samples after OCM process using mixture of (A) biogas1 $+\mathrm{O}_{2}+\mathrm{He}$ and (B) biogas $2+\mathrm{O}_{2}+\mathrm{He}(\mathbf{C}) \mathrm{CH}_{4}+\mathrm{O}_{2}+\mathrm{He}$, (D) $\mathrm{CH}_{4}+\mathrm{O}_{2}+\mathrm{CO}_{2}+\mathrm{He}$. Reaction conditions: $\mathrm{T}=1053 \mathrm{~K} ; \mathrm{GHSV}=11,550 \mathrm{~cm}^{3} \cdot \mathrm{g}^{-1}$ cat $\cdot \mathrm{h}^{-1} ; \mathrm{m}_{\text {cat }}=400 \mathrm{mg}$; total flow rate $=77$ $\mathrm{cm}^{3} \cdot \mathrm{min}^{-1}$; molar ratio (in all cases); $\mathrm{V}_{\mathrm{CH} 4}: \mathrm{V}_{\mathrm{O} 2}: \mathrm{V}_{\mathrm{He}}+\mathrm{CO} 2+\mathrm{N} 2=14.4: 4.3: 58.3$; Reaction time $=220$ $\min$.

Moreover, in the fresh and used $\mathrm{Mn}-\mathrm{Na}_{2} \mathrm{WO}_{4} / \mathrm{SiO}_{2}$ samples, small reflections characteristic of crystalline $\mathrm{Mn}_{2} \mathrm{O}_{3}$ were detected. The $\mathrm{Mn}_{2} \mathrm{O}_{3}$ signals are not observed for the $\mathrm{Mn} / \mathrm{SiO}_{2}$ sample, which can be explained either by high dispersion of the manganese phase on amorphous $\mathrm{SiO}_{2}$ in the absence of $\mathrm{Na}_{2} \mathrm{WO}_{4}$ or by a relatively low detection limit of the XRD technique. For the $\mathrm{Mn} / \mathrm{SiO}_{2}$ sample, only small reflections characteristic of the $\mathrm{Mn}_{3} \mathrm{O}_{4}$ spinel phase were found. In the fresh and used $\mathrm{Mn}-\mathrm{Na}_{2} \mathrm{WO}_{4} / \mathrm{SiO}_{2}$ catalyst, they overlap with much more intense peaks of $\alpha$-cristobalite and $\mathrm{Na}_{2} \mathrm{WO}_{4}$. To conclude, the XRD results of the used catalysts indicated the absence of significantly abundant new structures, regardless of the type of feedstock.

The chemical composition of the $\mathrm{Mn}-\mathrm{Na}_{2} \mathrm{WO}_{4} / \mathrm{SiO}_{2}$ catalyst surface were determined using the XPS spectra. Figure 2 shows the XPS Mn 2p, W $4 \mathrm{f}$ and $\mathrm{O}$ 1s spectra for the fresh and used catalysts. The Mn $2 \mathrm{p}$ spectra of all catalysts (fresh and used) show a doublet of Mn 2p3/2-Mn 2p1/2, at approximately $642 \mathrm{eV}$ and $653 \mathrm{eV}$. 


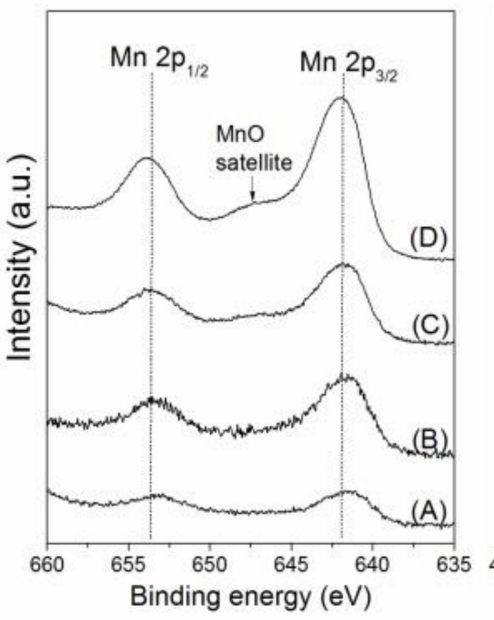

(a)

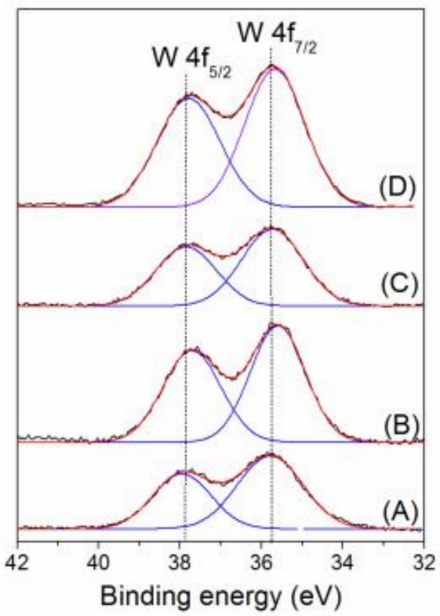

(b)

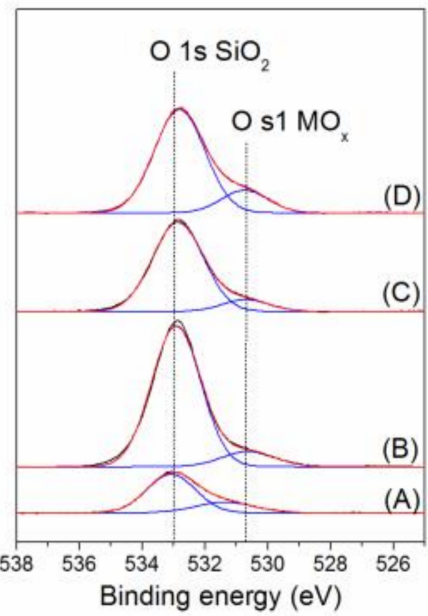

(c)

Figure 2. XPS spectra of (a) Mn 2p, (b) W $4 \mathrm{f}$ and (c) $\mathrm{O}$ 1s level for fresh and used $\mathrm{Mn}-\mathrm{Na}_{2} \mathrm{WO}_{4} / \mathrm{SiO}_{2}$ catalysts. (A) fresh catalyst; (B) used catalyst-feedstock biogas $1+\mathrm{O}_{2}+\mathrm{He},(\mathbf{C})$ used catalystfeedstock biogas $2+\mathrm{O}_{2}+\mathrm{He}$, (D) used catalyst-feedstock $\mathrm{CH}_{4}+\mathrm{O}_{2}+\mathrm{He}$.

Additionally, a small satellite is visible at $647 \mathrm{eV}$, indicating the existence of $\mathrm{Mn}^{2+}$ in addition to $\mathrm{Mn}^{3+}$ [62]. However, the clearly outlined satellite peak, indicating a higher concentration of $\mathrm{Mn}^{2+}$ on the catalyst surface, is observed only when the $\mathrm{CH}_{4}+\mathrm{O}_{2}+\mathrm{He}$ mixture is used as feedstock. The intensity of the $\mathrm{MnO}$ satellite depends on the degree of reduction of the catalyst; during the reoxidation of the catalyst, its intensity decreases [62]. The W $4 \mathrm{f}$ XPS spectra of the fresh and used catalyst (Figure 1) have spin-orbit doublets ca. at 36 and $38 \mathrm{eV}$ for $\mathrm{W} 4 \mathrm{f} 7 / 2$ and $\mathrm{W} 4 \mathrm{f} 5 / 2$, respectively, which were assigned to $\mathrm{W}$ ions with $6+$ oxidation state [62].

Table 2 shows binding energies and surface elemental compositions of the fresh catalyst $\mathrm{Mn}-\mathrm{Na}_{2} \mathrm{WO}_{4} / \mathrm{SiO}_{2}$ and the catalysts after the OCM process, when a mixture of unpurified biogas (biogas 1 or biogas 2) or pure $\mathrm{CH}_{4}$ with oxygen and inert gas (He) was used as a feedstock.

Table 2. XPS results for fresh and used $\mathrm{Mn}-\mathrm{Na}_{2} \mathrm{WO}_{4} / \mathrm{SiO}_{2}$ catalysts ${ }^{\mathrm{a}}$.

\begin{tabular}{|c|c|c|c|c|c|c|c|c|c|c|}
\hline \multirow[b]{2}{*}{ Feedstock } & \multicolumn{2}{|c|}{$\mathrm{Na}(1 \mathrm{~s})$} & \multicolumn{2}{|c|}{$W(4 f)$} & \multicolumn{2}{|c|}{$\operatorname{Mn}(2 p)$} & \multicolumn{2}{|c|}{$\mathrm{O}(1 \mathrm{~s}) \mathrm{SiO}_{2}$} & \multicolumn{2}{|c|}{$\mathrm{O}(1 \mathrm{~s}) \mathrm{MO}_{\mathrm{x}}$} \\
\hline & $\begin{array}{c}\text { BE } \\
(e V)\end{array}$ & $\begin{array}{c}\text { In } \\
\text { (at \%) }\end{array}$ & $\begin{array}{c}\mathrm{BE} \\
(\mathrm{eV})\end{array}$ & $\underset{\text { (at. \%) }}{\text { In }}$ & $\begin{array}{c}\text { BE } \\
(\mathrm{eV})\end{array}$ & $\underset{\text { (at.\%) }}{\text { In }}$ & $\begin{array}{c}\text { BE } \\
(\mathrm{eV})\end{array}$ & $\begin{array}{c}\text { In } \\
\text { (at. \%) }\end{array}$ & $\begin{array}{c}\text { BE } \\
(\mathrm{eV})\end{array}$ & $\begin{array}{c}\text { In } \\
\text { (at. \%) }\end{array}$ \\
\hline Fresh catalyst & 1071.7 & 4.48 & 36.0 & 0.71 & 642.7 & 0.62 & 533.1 & 30.96 & 530.7 & 9.25 \\
\hline $\mathrm{CH}_{4}+\mathrm{O}_{2}+\mathrm{He}$ & 1071.7 & 4.89 & 36.0 & 0.82 & 642.5 & 1.57 & 533.0 & 45.71 & 530.6 & 12.9 \\
\hline Biogas $1+\mathrm{O}_{2}+\mathrm{He}$ & 1071.9 & 2.24 & 35.9 & 0.61 & 641.6 & 0.96 & 533.0 & 55.22 & 530.7 & 6.37 \\
\hline Biogas $2+\mathrm{O}_{2}+\mathrm{He}$ & 1072.1 & 3.27 & 35.9 & 0.58 & 642.1 & 1.16 & 532.8 & 54.37 & 530.5 & 7.22 \\
\hline
\end{tabular}

a Used samples after OCM reaction carried out at $\mathrm{T}=1053 \mathrm{~K}$; GHSV $=11550 \mathrm{~cm}^{3} \cdot \mathrm{g}^{-1}$ cat $\cdot \mathrm{h}^{-1}$. $\mathrm{m}_{\text {cat }}=400 \mathrm{mg}$; total flow rate $=77 \mathrm{~cm}^{3} \cdot \min ^{-1}$; molar ratio (in all cases); $\mathrm{V}_{\mathrm{CH} 4}: \mathrm{V}_{\mathrm{O} 2}: \mathrm{V}_{\mathrm{He}}+\mathrm{CO} 2+\mathrm{N} 2$ $=14.4: 4.3: 58.3$, reaction time $=220 \mathrm{~min}$.

The highest concentration of $\mathrm{Na}$ at the surface was found in the case of the fresh catalyst and the catalyst after the process, when a mixture $\mathrm{CH}_{4}+\mathrm{O}_{2}+\mathrm{He}$ was used as a feedstock. The use of raw biogas as a feedstock reduced the concentration of sodium ions at the catalyst surface, although in all cases the $\mathrm{Na} / \mathrm{W}$ ratio on the surface was higher than 2, which indicates that some of the $\mathrm{Na}$ ions at the surface are not present in the form of the $\mathrm{Na}_{2} \mathrm{WO}_{4}$ compound, probably only in the form of $\mathrm{Na}_{2} \mathrm{O}$ or $\mathrm{Na}_{2} \mathrm{O}_{2}$ [55].

The surface concentration of $\mathrm{Na}$ and $\mathrm{W}$ was higher on the catalyst used in the process, when the $\mathrm{CH}_{4}+\mathrm{O}_{2}+\mathrm{He}$ mixture was used as a feedstock, than on the surface of the fresh catalyst, indicating that some of the $\mathrm{Na}$ and $\mathrm{W}$ migrated from the mass to the surface. A 
different situation was observed when raw biogas (1 and 2) was used as a feedstock. In this case, the concentration of $\mathrm{Na}$ and $\mathrm{W}$ on the surface was lower than on the fresh catalyst. Shi et al. [55] also observed a decrease of $\mathrm{Na}$ and $\mathrm{W}$ at the surface at high concentrations of $\mathrm{CO}_{2}$ in the feedstock as well as when the inert gas contribution in the feed stream was increased. The surface concentration of $\mathrm{Mn}$ in the used catalysts (regardless of the type of feedstock) is higher than in the case of the fresh catalyst, wherein it is the highest in the case of the $\mathrm{CH}_{4}+\mathrm{O}_{2}+\mathrm{He}$ mixture. Shi et al. [55] observed that the concentration of $\mathrm{Mn}$ increases with increasing $\mathrm{CO}_{2}$ concentration in the feed stream and decreases with dilution of inert gas reagents. As a result of the XPS O1 spectra deconvolution two peaks were obtained. The peak at about $533 \mathrm{eV}$ corresponded to the $\mathrm{O}$ atoms bound in the $\mathrm{SiO}_{2}$ form and the other peak at about $530 \mathrm{eV}$ corresponded to the $\mathrm{O}$ atom in the metal oxides $\left(\mathrm{MO}_{\mathrm{x}}\right)$. Oxygen present in the metal oxides has been recognized as surface active species of oxygen $[55,58]$.

Table 2 shows the percentage contribution of oxygen atoms in $\mathrm{MO}_{\mathrm{x}}$ and $\mathrm{SiO}_{2}$ on the fresh and used catalysts. The amount of oxygen bound in the form of MOx is much greater for the fresh catalyst and the catalyst after the process in which the $\mathrm{CH}_{4}+\mathrm{O}_{2}+\mathrm{He}$ mixture was used, than on the catalysts used in the process with biogas as a feedstock-then the amount of surface oxygen species (associated with the metal ions- $\mathrm{MO}_{\mathrm{x}}$ ) decreased significantly, i.e., by almost a half (in the case of both types of biogas).

Catalysts with lower $\mathrm{Na}$ and $\mathrm{W}$ ion concentrations on the surface also had lower $\mathrm{MO}_{\mathrm{x}}$-bound oxygen concentrations. The concentration of $\mathrm{Na}$ and $\mathrm{W}$ ions, as well as $\mathrm{O}$ in $\mathrm{MO}_{\mathrm{x}}$ on the surface of the $\mathrm{Mn}-\mathrm{Na}_{2} \mathrm{WO}_{4} / \mathrm{SiO}_{2}$ catalyst, was significantly lower when raw biogas was used, compared to the fresh catalyst and treated with the pure methane + oxygen mixture. At the same time, regardless of the type of biogas used (biogas1 or biogas2), the concentrations of $\mathrm{Na}, \mathrm{W}, \mathrm{O}$ in $\mathrm{MO}_{\mathrm{x}}$ were similar. This correlation, i.e., an increase in the concentration of $\mathrm{O}$ in $\mathrm{MO}_{\mathrm{x}}$ with an increase in the concentration of $\mathrm{Na}$ and $\mathrm{W}$ ions, was observed also by Shi et al. [55]. The changes in the surface concentration of $\mathrm{Na}, \mathrm{W}$ and $\mathrm{O}$ in $\mathrm{MO}_{\mathrm{x}}$ on the catalyst are also influenced by the dilution of the feedstock with the $\mathrm{CO}_{2}$ and inert gas [55]. It can be concluded that the migration of $\mathrm{Na}$ and $\mathrm{W}$ to the catalyst surface increases the storage capacity of surface active oxygen species [55].

XPS experiments confirm the absence of sulphur- or nitrogen-containing compounds on the surface of used catalysts. Indeed $\mathrm{Gu}$ et al. [49] found the presence of $\mathrm{Na}_{2} \mathrm{SO}_{4}$, based on the XPS studies, but the contribution of $\mathrm{H}_{2} \mathrm{~S}$ used in the research was very high, i.e., the share of $\mathrm{H}_{2} \mathrm{~S}$ in the stream was $0.33 \% \mathrm{~mol}$, while the share of $\mathrm{H}_{2} \mathrm{~S}$ in biogas was 0-2000 ppm [11].

To determine the effect of surface carbonates on the catalytic behaviour of Mn$\mathrm{Na}_{2} \mathrm{WO}_{4} / \mathrm{SiO}_{2}$, temperature-programmed desorption (TPD) of $\mathrm{CO}_{2}$ was carried out (Figure 3). In this experiment, a fresh $\mathrm{Mn}-\mathrm{Na}_{2} \mathrm{WO}_{4} / \mathrm{SiO}_{2}$ sample was treated in a pure $\mathrm{CO}_{2}$ stream at various increasing temperatures $(298,923,973,1023,1073$, and $1123 \mathrm{~K})$, and after cooling down, TPD profiles were recorded. All profiles in Figure 3 exhibit a small desorption maximum c.a. of $1100-1120 \mathrm{~K}$, which confirms that the surface $\mathrm{Na}_{2} \mathrm{CO}_{3}$ is present at any investigated temperature. Semi-quantitative $\mathrm{CO}_{2}$-TPD results (inset to Figure 3) indicate that the concentration of surface carbonates decreases rapidly above $1073 \mathrm{~K}$. This correlates with the poisoning effect of $\mathrm{CO}_{2}$ depicted in Figure S1A (Supplementary Materials) suggesting slight suppression of the OCM activity by high concentration of $\mathrm{Na}_{2} \mathrm{CO}_{3}$ on the surface of $\mathrm{Mn}-\mathrm{Na}_{2} \mathrm{WO}_{4} / \mathrm{SiO}_{2}$. The poisoning effect of $\mathrm{CO}_{2}$ on $\mathrm{CH}_{4}$ conversion is cancelled out above $1073 \mathrm{~K}$, when the concentration of the surface $\mathrm{Na}_{2} \mathrm{CO}_{3}$ decreases rapidly. The effect of $\mathrm{CO}_{2}$ on selectivity to $\mathrm{C}_{2+}$ is more complicated. Two inverse effects need to be considered. The first one, connected with the formation of less active and selective carbonates, is OCM retardation by surface poisoning. The second effect is positive probably due to the suppression of side reactions of methyl radicals with oxidized species. Such a promoting role of $\mathrm{CO}_{2}$ on selectivity was reported over the $\mathrm{Li} / \mathrm{MgO}$ catalyst $[63,64]$. It was found that in the presence of $\mathrm{CO}_{2}$ the selectivity increases because the probability of methyl radicals coupling is enhanced with respect to the probability of their oxidation to $\mathrm{CO}_{2}$ via 
methoxide ions [63]. Our study indicates that the first poisoning effect predominates at low temperatures while the second positive effect dominates at high temperatures when the concentration of the surface $\mathrm{Na}_{2} \mathrm{CO}_{3}$ is relatively low.

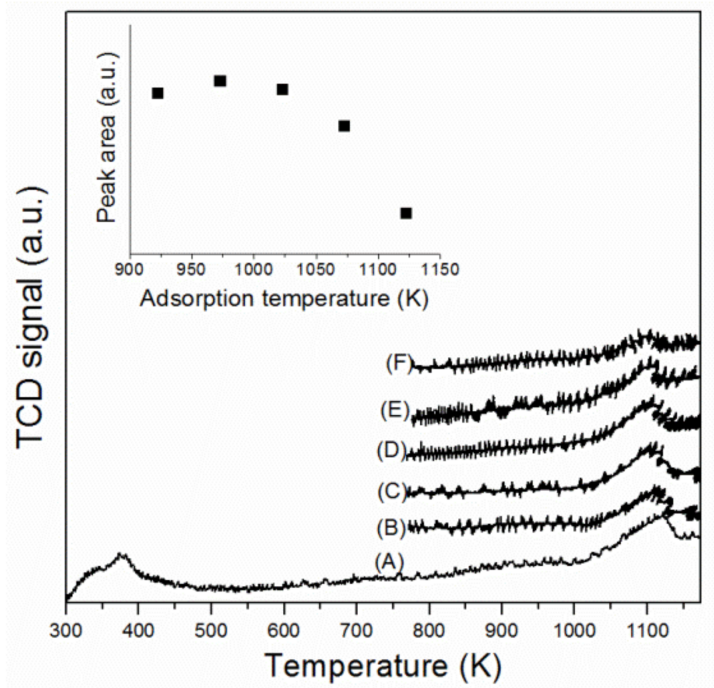

Figure 3. Temperature-programmed desorption of $\mathrm{CO}_{2}$ for the $\mathrm{Mn}-\mathrm{Na}_{2} \mathrm{WO}_{4} / \mathrm{SiO}_{2}$ sample. Experiment conditions: heating rate $10 \mathrm{~K} / \mathrm{min}$; $\mathrm{CO}_{2}$ adsorption temperatures: (A) 298, (B) 923, (C) 973, (D) 1023, (E) 1073 and (F) $1123 \mathrm{~K}$.

\subsection{Catalytic Performance}

Figure 4 displays the temperature effect on the catalytic performance of $\mathrm{Mn}-\mathrm{Na}_{2} \mathrm{WO}_{4} / \mathrm{SiO}_{2}$ in the presence of raw biogas (biogas 1) as a source of methane. The tests were carried out in the temperature range of $1013-1113 \mathrm{~K}$. In the temperature range of $1013 \mathrm{~K}-1053 \mathrm{~K}$, the conversion of methane, selectivity to $C_{2}$ and the molar ratio ethylene/ethane increase with an increase in temperature. Above $1053 \mathrm{~K}$, the selectivity to $C_{2}$ decreases, and the conversion of methane in the temperature range of $1073 \mathrm{~K}-1113 \mathrm{~K}$ does not change. At a molar ratio of $\mathrm{CH}_{4} / \mathrm{O}_{2}$ equal 3.3 and a volumetric flow rate of $\mathrm{V}=77 \mathrm{~cm}^{3} / \mathrm{min}$, when "biogas 1 " was used as a feed, the optimal temperature range for the OCM process was $1053 \mathrm{~K}-1073 \mathrm{~K}$. These observations are consistent with the literature, which show that obtaining high ethylene yields in the OCM process carried out in the presence of the $\mathrm{Mn}-\mathrm{Na}_{2} \mathrm{WO}_{4} / \mathrm{SiO}_{2}$ catalyst requires the use of high temperatures of $1053 \mathrm{~K}-1123 \mathrm{~K}[65,66]$. The process of OCM is also significantly influenced by the methane/oxygen molar ratio in the feed stream. Tests are usually conducted at a methane/oxygen molar ratio of 2-7 [65-67], although it has been shown that in the presence of the $\mathrm{Mn}-\mathrm{Na}_{2} \mathrm{WO}_{4} / \mathrm{SiO}_{2}$ catalyst the highest $\mathrm{C}_{2}$ yield can be achieved with a methane/oxygen ratio in the range of 2-4 [66,68]. A high concentration of oxygen in the feed stream favours the conversion of methane, as well as ethane, to ethylene dehydrogenation processes, hence the higher the ethylene/ethane ratio, the lower the methane/oxygen molar ratio. Unfortunately, a high concentration of oxygen in the feed stream also favours over oxidation reactions in which carbon oxides $\mathrm{CO}_{\mathrm{x}}$ are formed, therefore, with an increase of the methane/oxygen molar ratio, the selectivity to $C_{2}$ decreases [68]. This trend was also observed when biogas was used as a source of methane (Figure 5).

The addition of $\mathrm{CO}_{2}$ to the reaction stream exerts a small poisoning effect on methane conversion, but at the same time it promotes selectivity to $\mathrm{C}_{2+}$ (Figure S1). This effect rises with an increase in the partial pressure of $\mathrm{CO}_{2}$, however only for the low-pressure range (below $26 \mathrm{kPa}$ ). At a higher partial pressure of $\mathrm{CO}_{2}$, both the conversion of $\mathrm{CH}_{4}$ and selectivity to $\mathrm{C}_{2+}$ remain almost constant. As was mentioned above, the presence of $\mathrm{CO}_{2}$ in the stream inhibits the oxidation of $\mathrm{CH}_{4}$ and $\mathrm{C}_{2+}$ hydrocarbons to $\mathrm{CO}_{\mathrm{x}}$, probably by poisoning sites responsible for a deep oxidation that leading to an increase in $C_{2}$ 
selectivity $[69,70]$. Contrary to this, the negative effect of $\mathrm{CO}_{2}$ is associated with the poisoning of the active sites for the coupling reaction. By competitive chemisorption of carbon dioxide and oxygen on the same active sites the amount of converted methane and the amount of $\mathrm{C}_{2+}$ products are reduced.

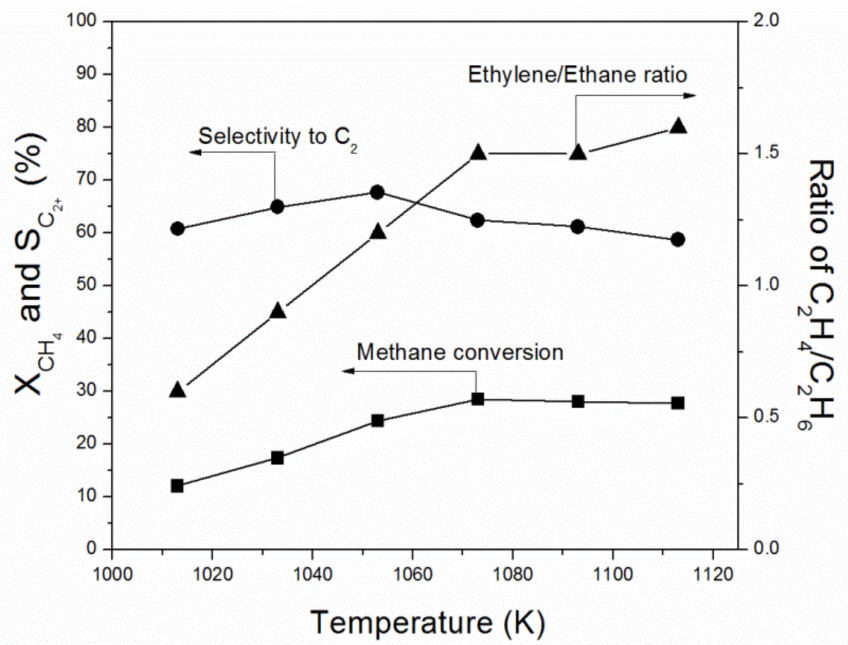

Figure 4. The influence of temperature on the OCM process. Source of methane- “biogas 1". Reaction conditions: GHSV $=11550 \mathrm{~cm}^{3} \cdot \mathrm{g}^{-1}$ cat $\cdot \mathrm{h}^{-1} ; \mathrm{m}_{\text {cat }}=400 \mathrm{mg}$; molar ratio of $\mathrm{CH}_{4}: \mathrm{O}_{2}: \mathrm{CO}_{2}: \mathrm{He}+\mathrm{N}_{2}=$ 3.3:1:1.2:12.4; total flow rate $=77 \mathrm{~cm}^{3} \cdot \mathrm{min}^{-1}$.

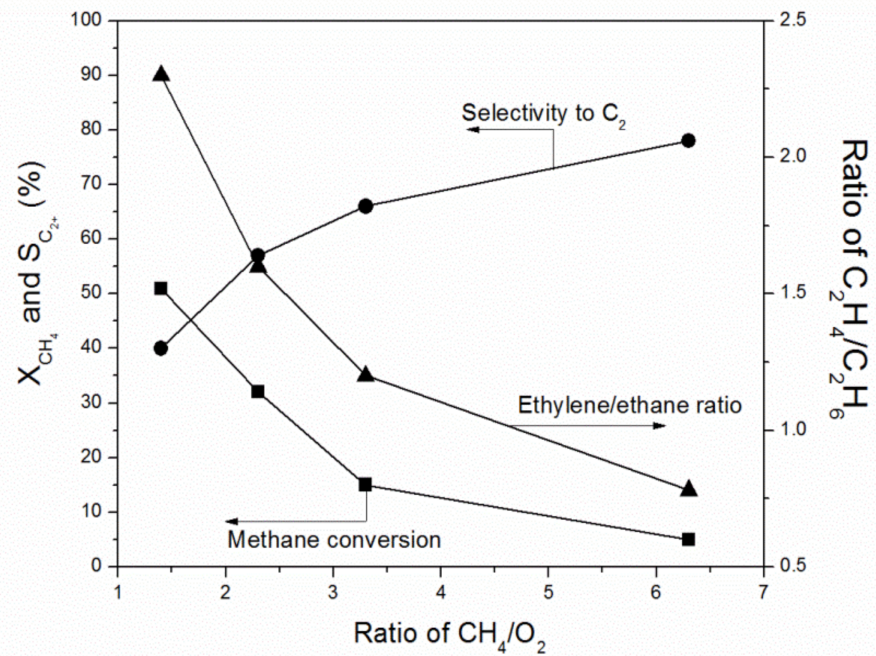

Figure 5. Influence of the methane/oxygen molar ratio on the OCM process. Source of methane"biogas 1". Reaction conditions: $\mathrm{T}=1053 \mathrm{~K} ; \mathrm{GHSV}=11550 \mathrm{~cm}^{3} \cdot \mathrm{g}^{-1} \mathrm{cat} \cdot \mathrm{h}^{-1} ; \mathrm{m}_{\text {cat }}=400 \mathrm{mg}$; total flow rate $=77 \mathrm{~cm}^{3} \cdot \min ^{-1}$, molar ratio of $\mathrm{CH}_{4}: \mathrm{O}_{2}: \mathrm{CO}_{2}: \mathrm{He}+\mathrm{N}_{2}=1.4: 1: 0.5: 4.6 ; \mathrm{CH}_{4}: \mathrm{O}_{2}: \mathrm{CO}_{2}: \mathrm{He}+$ $\mathrm{N}_{2}=2.3: 1: 0.8: 8.1 ; \mathrm{CH}_{4}: \mathrm{O}_{2}: \mathrm{CO}_{2}: \mathrm{He}+\mathrm{N}_{2}=3.3: 1: 1.2: 12.4 ; \mathrm{CH}_{4}: \mathrm{O}_{2}: \mathrm{CO}_{2}: \mathrm{He}+\mathrm{N}_{2}=6.3: 1: 2.2: 24: 25$.

Often, the poisoning effect of $\mathrm{CO}_{2}$ is explained by blocking the active sites by surface carbonates generated in situ during the OCM process [71,72]. In the case of the mixed $\mathrm{Mn}$ $\mathrm{Na}_{2} \mathrm{WO}_{4}$ catalysts, two carbonates, i.e., $\mathrm{MnCO}_{3}$ and $\mathrm{Na}_{2} \mathrm{CO}_{3}$, may be produced. However, under the OCM conditions, $\mathrm{Na}_{2} \mathrm{CO}_{3}$ is the only stable carbonate. Wang et al. [73] have reported that $\mathrm{Na}_{2} \mathrm{CO}_{3}$ decomposes between 773-1173 K. Moreover, based on the XPS data, they have estimated that in $\mathrm{Mn}-\mathrm{Na}_{2} \mathrm{WO}_{4}$ containing catalysts, $20-40 \%$ of surface sodium cations are in the form of $\mathrm{Na}_{2} \mathrm{CO}_{3}$ after the process carried out at $1073 \mathrm{~K}$ [71]. In a classical OCM process, the carbonates originate from the $\mathrm{CO}_{2}$ produced in a total oxidation reaction, whereas the $\mathrm{CO}_{2}$ introduced intentionally into the stream of reagents 
can be an additional factor enhancing the concentration of surface $\mathrm{Na}_{2} \mathrm{CO}_{3}$ species leading to the observed changes in catalytic behaviour. Moreover, $\mathrm{CO}_{2}$ may have impact on the $\mathrm{Mn}-\mathrm{Na}_{2} \mathrm{WO}_{4} / \mathrm{SiO}_{2}$ catalyst structure by changing the interaction between $\mathrm{Na}^{+}$and $\mathrm{WO}_{4}{ }^{2-}$ as well as the structure of $\mathrm{W}$ species, that is, $\mathrm{WO}_{4}$ or $\mathrm{WO}_{6}$ [55]. Shi et al. [55] found that low concentrations of $\mathrm{CO}_{2}$ favour the formation selective in $\mathrm{OCM} \mathrm{Na} \mathrm{WO}_{4}$ sites with tetrahedral $\mathrm{WO}_{4}$ sites, while increasing the $\mathrm{CO}_{2}$ concentration in the feed stream weakens $\mathrm{Na}^{+}$and $\mathrm{WO}_{4}{ }^{2-}$ interaction and leads to generation less active and selective $\mathrm{MnWO}_{4}$.

The OCM process, which was carried out alternately using a gas stream with and without $\mathrm{CO}_{2}$ (Figure S2), showed that each time $\mathrm{CO}_{2}$ was added to reagents the stream selectivity to $\mathrm{C}_{2+}$ increased, while at the same time the conversion of methane decreased slightly. The effect of $\mathrm{CO}_{2}$ disappears after its removal from the reagents stream (replacing $\mathrm{CO}_{2}$ with an inert gas). This indicates clearly that under the experiment conditions $\mathrm{CO}_{2}$ does not modify the surface of $\mathrm{Mn}-\mathrm{Na}_{2} \mathrm{WO}_{4} / \mathrm{SiO}_{2}$ permanently.

The effect of $\mathrm{CO}_{2}$ on the process also depends on temperature and oxygen concentration (Figure S3). Up to $1073 \mathrm{~K}, \mathrm{CO}_{2}$ exerts a poisoning effect on the conversion of $\mathrm{CH}_{4}$, while above this temperature (at $1123 \mathrm{~K}$ ) the conversion is similar for a process with and without $\mathrm{CO}_{2}$. The addition of $\mathrm{CO}_{2}$ has a similar poisoning effect on selectivity to $\mathrm{C}_{2+}$. In this case, however, starting from $1073 \mathrm{~K}$, the $\mathrm{CO}_{2}$ addition promotes selectivity to $\mathrm{C}_{2+}$. This result indicates clearly that the negative effect of $\mathrm{CO}_{2}$ on OCM can be cancelled out by a temperature increase above $1073 \mathrm{~K}$.

A significant influence of $\mathrm{CO}_{2}$ on the $\mathrm{OCM}$ process was also visible in the case of using raw biogas. Figure 6 shows the influence of the feed composition on selectivity to $\mathrm{C}_{2}$, the methane conversion and the ethylene/ethane molar ratio. A higher $C_{2}$ selectivity was observed when $\mathrm{CO}_{2}$ was present in the stream, while the methane conversion and ethylene/ethane molar ratio were slightly lower than in the absence of carbon dioxide.

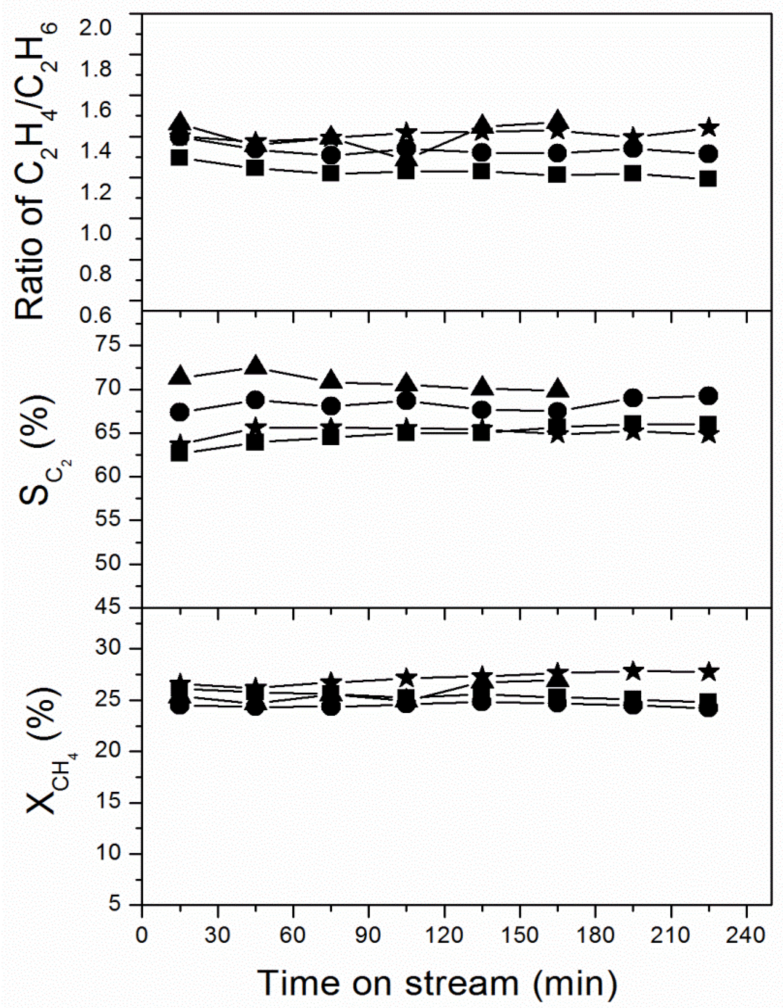

Figure 6. Influence of feedstock composition on methane conversion, selectivity to $\mathrm{C}_{2}$ and ethylene/ethane molar ratio. Reaction conditions: $\mathrm{T}=1053 \mathrm{~K} ; \mathrm{GHSV}=11,550 \mathrm{~cm}^{3} \cdot \mathrm{g}^{-1} \mathrm{cat} \cdot \mathrm{h}^{-1}$; $\mathrm{m}_{\text {cat }}=400 \mathrm{mg}$; total flow rate $=77 \mathrm{~cm}^{3} \cdot \mathrm{min}^{-1} ;$ molar ratio of $\mathrm{CH}_{4}: \mathrm{O}_{2}=3.3$ (in all cases); $\mathrm{V}_{\mathrm{CH} 4}: \mathrm{V}_{\mathrm{O} 2}: \mathrm{V}_{\mathrm{He}}+\mathrm{CO} 2+\mathrm{N} 2=14.4: 4.3: 58.3$. Symbols: $(\boldsymbol{\square})$ biogas 1 (as source of methane), $(\boldsymbol{\Delta})$ biogas 2 (as source of methane), $(\bullet)$ mixture of $\mathrm{CH}_{4}+\mathrm{CO}_{2}+\mathrm{O}_{2}+\mathrm{He},(\star)$ mixture of $\mathrm{CH}_{4}+\mathrm{O}_{2}+\mathrm{He}$. 
The highest selectivity to $\mathrm{C}_{2}$ was obtained by using "biogas 2 ". Similar results were obtained when a mixture composed of pure components (i.e., methane, oxygen, carbon dioxide and helium), simulating the composition of biogas 2, was used. The use of a mixture devoid of carbon dioxide $\left(\mathrm{CO}_{2}\right.$ was replaced with helium) resulted in decreasing the selectivity to $\mathrm{C}_{2}$ and increasing the conversion rate of methane. Similar results as in the case of the $\mathrm{CH}_{4}+\mathrm{O}_{2}+\mathrm{He}$ mixture were obtained with the use of raw "biogas 1", i.e., a mixture poor in $\mathrm{CO}_{2}$. The methane conversion, regardless of the composition of feedstock used, differed slightly, i.e., by about 3\%. In the tested period of time, regardless of the type of feedstock used, the $\mathrm{Mn}-\mathrm{Na}_{2} \mathrm{WO}_{4} / \mathrm{SiO}_{2}$ catalyst worked stably (Figure 6).

The presence of an inert gas influences the catalytic performance in the OCM process as well. The results presented in Figure 7 were obtained using the feedstock diluted with helium and/or carbon dioxide and nitrogen (the presence of carbon dioxide and nitrogen results from its presence in biogas). The total contribution of these gases (helium, carbon dioxide and nitrogen) to the reaction mixture was $43 \%$ (vol.). Reducing the contribution of helium in the feed stream to less than $30 \%$ (vol.) while maintaining the volumetric flow rate (Figure 7) causes an increase in the methane conversion and the ethylene/ethane molar ratio, and decreases selectivity to $C_{2}$. This effect is independent of the type of raw material used. Diluting the feed stream with helium, keeping the biogas/methane and oxygen flow rate constant, but increasing the total volumetric flow rate of the feed stream lowers the methane conversion and the ethylene/ethane molar ratio. Selectivity to $C_{2}$, in the range up to $80 \mathrm{~cm}^{3} \cdot \mathrm{min}^{-1}$, increases with an increasing proportion of inert gas in the reaction mixture, and then decreases (Figure 6). Dilution of the reactants stream with inert gas had a negative effect on the methane conversion and the ethylene/ethane molar ratio, but a positive one on selectivity to $C_{2}$. However, the positive effect on the selectivity to $C_{2}$ was observed only when the contribution of helium to the feed stream was about $70 \%$.

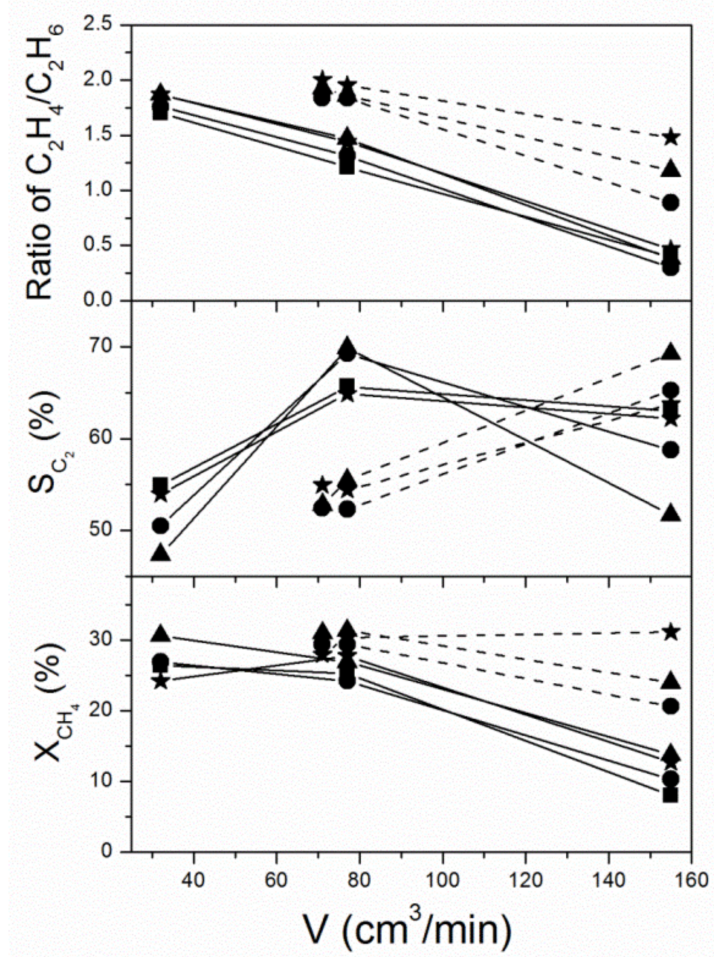

Figure 7. Influence of diluting feedstock with inert gas (helium) on the OCM process. Reaction conditions: $\mathrm{T}=1053 \mathrm{~K} ; \mathrm{m}_{\text {cat }}=400 \mathrm{mg}$; molar ratio of $\mathrm{CH}_{4}: \mathrm{O}_{2}=3.3$ (in all cases); total flow rate $=77 \mathrm{~cm}^{3} \cdot \mathrm{min}^{-1} ; \mathrm{V}_{\mathrm{CH} 4}: \mathrm{V}_{\mathrm{O} 2}=14.4: 4.3$ (solid line); $\mathrm{V}_{\mathrm{CH} 4}: \mathrm{V}_{\mathrm{O} 2}:=37.8: 11.3$ (dotted line). Sym-

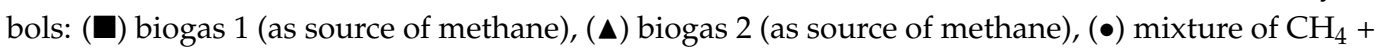
$\mathrm{CO}_{2}+\mathrm{O}_{2}+\mathrm{He},(\star)$ mixture of $\mathrm{CH}_{4}+\mathrm{O}_{2}+\mathrm{He}$. 
As shown in Figure 7, GHSV has an effect on the conversion of methane and selectivity to $\mathrm{C}_{2}$. Increasing the GHSV causes a decrease in the conversion of methane and the ethylene/ethane molar ratio, while increasing selectivity to $\mathrm{C}_{2}$. At low GHSV, the conversion of methane is low and the main product is $\mathrm{C}_{2} \mathrm{H}_{6}$ [74]. With the extension of the residence time, the conversion of methane and the selectivity to ethylene increase, but the selectivity to ethane lowers [74,75], because most of the $\mathrm{C}_{2} \mathrm{H}_{4}$ is formed via $\mathrm{C}_{2} \mathrm{H}_{6}$ [74].

A similar direction of changes in catalytic properties was also observed in the case of the OCM process carried out on other catalysts previously [74-77]. It was found that gas hourly space velocity (GHSV), flow rate and contact time have an impact on both conversion and product distribution.

\section{Materials and Methods}

\subsection{Feedstock}

Two types of raw, unpurified biogas were used for the research. Biogas obtained from plant materials, labelled "biogas 1" and biogas derived from waste of animal origin, labelled "biogas 2", were used as feedstock. "Biogas 1" was made from potato pulp, beet pulp and Corn-Cob-Mix. Each of the raw materials was anaerobically digested in a separate glass reactors. The biogas obtained from the vegetable raw materials was mixed and labelled "biogas 1". To produce "biogas 2", waste from carp processing was used.

The collected waste was homogenized, and its moisture content and dry organic matter content were determined. The biomass was hydrated to $90 \%$ humidity, which is the optimal humidity for wet methane fermentation, and then placed in $2 \mathrm{dm}^{3}$ fermenters, along with the inoculum. The support material was digestate from an agricultural biogas plant. Each batch was divided into four such fermenters plus a fermenter containing only the inoculum. The fermenter with inoculum was a reference object against which yields from each fermenter were compared. Thus, prepared fermenters were placed in a chamber with temperature control. Next, the samples were subjected to static methane fermentation, according to the methodology of DIM DIN 38414. It consisted of a single introduction of substrates into the fermentation chambers and the carrying out of the process until its completion. The $\mathrm{pH}$ in the fermenters was maintained at 6.5-6.9 due to the alkalinity of the fats present in the fermented biomass. The appropriate $\mathrm{pH}$ was maintained due to the inoculation additive. The methane fermentation process lasted 30 days. The gas resulting from methane fermentation was collected in variable volume tanks for each fermenter. The NANO SENS $60 \mathrm{~m}$ was used to measure the moisture content of the produced biogas and to determine its chemical composition. The results of the parameters of the process carried out were read daily at the same time and automatically saved to the computer disk using measuring software. Details on the process of obtaining biogas 1 and biogas 2 have been described in the literature [78,79].

Biogas 1 and biogas 2 composition were analysed using a gas chromatograph, the Agilent 6890N (Agilent Technology, Santa Clara, CA, USA) equipped with two columns (molecular sieve 5A for the analysis of $\mathrm{N}_{2}, \mathrm{CO}$ and $\mathrm{O}_{2}$ and Hayesep $\mathrm{Q}$ for the analysis of $\mathrm{H}_{2}, \mathrm{CO}_{2}$, and hydrocarbons) and TCD. Based on chromatographic analyses, the content of the main biogas components (ie $\mathrm{CH}_{4}, \mathrm{CO}_{2}, \mathrm{~N}_{2}$ and $\mathrm{O}_{2}$ ) was determined. In "biogas1", the volume ratio of $\mathrm{CH}_{4}: \mathrm{CO}_{2}: \mathrm{O}_{2}: \mathrm{N}_{2}=1: 0.34: 0.014: 0.052$, and in "biogas2" it was $\mathrm{CH}_{4}: \mathrm{CO}_{2}: \mathrm{O}_{2}: \mathrm{N}_{2}=1: 0.57: 0.016: 0.06$. Moreover, the following mixture was used for the tests: $\mathrm{CH}_{4}\left(99.95 \%\right.$ Linde Gaz Polska) $+\mathrm{O}_{2}\left(99.96 \%\right.$ Linde Gaz Polska) $+\mathrm{CO}_{2}(99.96 \%$ BOC-Gaz) + He (99.999\%-BOC-Gaz), in which the contents of methane and carbon dioxide corresponded to those of biogas 2. Comparative tests were also carried out also using the mixture $\mathrm{CH}_{4}+\mathrm{O}_{2}(99.95 \%)$-Linde Gaz Polska + He (99.999\%—BOC-Gaz).

\subsection{Catalysts Preparation}

The catalysts were prepared by the impregnation technique. Dry-silica gel pore size 60 A, 35-60 mesh particle size (Sigma-Aldrich) was impregnated at room temperature by the incipient wetness method with an aqueous solution of $\mathrm{Mn}\left(\mathrm{NO}_{3}\right)_{2} \times 4 \mathrm{H}_{2} \mathrm{O}(97 \%$, 
CHEMPUR) or / and $\mathrm{Na}_{2} \mathrm{WO}_{4}(99 \%$, Aldrich,. In a typical procedure, $1 \mathrm{~g}$ of silica was impregnated with $1 \mathrm{~cm}^{3}$ of a solution containing desirable content of each salt needed for obtaining 2 and $5 \mathrm{wt} \%$ of $\mathrm{Mn}$ and $\mathrm{Na}_{2} \mathrm{WO}_{4}$, respectively. After impregnation the materials were dried for $15 \mathrm{~h}$ at $393 \mathrm{~K}$ and calcined at $1173 \mathrm{~K}$ for $8 \mathrm{~h}$. The $\mathrm{Mn}-\mathrm{Na}_{2} \mathrm{WO}_{4} / \mathrm{SiO}_{2}$ catalyst was obtained by impregnation of $\mathrm{SiO}_{2}$ in two steps with an aqueous solution of $\mathrm{Mn}\left(\mathrm{NO}_{3}\right)_{2}$ $\times 4 \mathrm{H}_{2} \mathrm{O}$ and $\mathrm{Na}_{2} \mathrm{WO}_{4}$ (Aldrich), respectively. After each impregnation, the materials were dried for $15 \mathrm{~h}$ at $393 \mathrm{~K}$. The dried materials (after the second impregnation step) were calcined at $1173 \mathrm{~K}$ for $8 \mathrm{~h}$. Obtained in this manner, catalysts were pelleted and crushed to obtain a fraction with a grain size of $0.2-0.3 \mathrm{~mm}$.

\subsection{Catalysts Characterization}

Powder X-ray diffraction (XRD) patterns were collected on an X'Pert Pro instrument (Panalytical, Almelo, Netherlands) operated at $40 \mathrm{kV}$ and $30 \mathrm{~mA}$, equipped with a $\mathrm{Cu} \mathrm{K} \alpha$ $(\lambda=0.154 \mathrm{~nm}) \mathrm{X}$-ray radiation source. The diffractograms were recorded in the $2 \theta$ range between $10^{\circ}$ and $70^{\circ}$ with a $2 \theta$ step size of $0.0167^{\circ}$.

Nitrogen adsorption-desorption isotherms were measured at 77K using a ASAP 2020 instrument (Micrometrics, Norcross, GA, USA). The samples were degassed at $523 \mathrm{~K}$ before measurements for $12 \mathrm{~h}$ in a degas port of the sorption analyser. Specific surface areas were calculated using the Brunauer-Emmett-Teller (BET) method within the relative pressure range of $\mathrm{P} / \mathrm{P} 0=0.05-0.15$. Total pore volumes were obtained from the amount of nitrogen adsorbed at $\mathrm{P} / \mathrm{P} 0=0.95$ or near that value.

The analysis of the temperature programmed desorption of carbon dioxide $\left(\mathrm{CO}_{2}-\mathrm{TPD}\right)$ was conducted in the quartz micro-reactor using TCD. Before measurement each sample $(1.00 \mathrm{~g})$ of catalyst was outgassed at a temperature of $1223 \mathrm{~K}$ under a dry helium stream $\left(1 \mathrm{~h}, \mathrm{~V}_{\mathrm{He}}=30 \mathrm{~cm}^{3} / \mathrm{min}\right.$.). After cooling to set temperature $(298 \mathrm{~K}, 923 \mathrm{~K}, 973 \mathrm{~K}, 1023 \mathrm{~K}$, $1073 \mathrm{~K}$ or $1123 \mathrm{~K}$ ) an adsorption of pure $\mathrm{CO}_{2}$ was carried out at for $0.5 \mathrm{~h}$. The excess of non-adsorbed $\mathrm{CO}_{2}$ was removed at the set temperature by flushing the sample with dry helium for $0.3 \mathrm{~h}$. After that the temperature was lowered to $773 \mathrm{~K}$ and desorption of $\mathrm{CO}_{2}$ was carried out using a linear temperature rise with a ramp of $10 \mathrm{~K} / \mathrm{min}$.

A photoelectron spectrometer (ESCA/XPS) with an EA15 semispherical analyser (PREVAC, Rogów, Poland) was used for the XPS analysis. The source of $\mathrm{Al} \mathrm{K \alpha}$ radiation $(1486.6 \mathrm{eV})$ was the RS 40B1 lamp (PREVAC) with the power of $180 \mathrm{~W}$. The spectra were processed with the program CasaXPS 2.3.15. The electron binding energy (BE) scale has been calibrated using the maximum of $\mathrm{Si} 2 \mathrm{p} 3 / 2$ signal with $\mathrm{BE}=103.5 \mathrm{eV}$.

\subsection{Catalytic Performance}

Catalytic tests were carried out in a continuous flow quartz reactor with the following dimensions: (external diameter) $\times($ length $) \times($ wall thickness $)=10 \times 270 \times 1 \mathrm{~mm}$. The weight of the catalyst was $400 \mathrm{mg}$ (grain size $0.2-0.3 \mathrm{~mm}$ ) and the temperature of the process was in the range between $1013 \mathrm{~K}$ and $1113 \mathrm{~K}$ (usually $1053 \mathrm{~K}$ ). The methane/oxygen volumetric ratio was from 1.4 to 6.3 (typically $\mathrm{CH}_{4} / \mathrm{O}_{2}=3.3$ ), and the total volumetric flow rate was $77 \mathrm{~cm}^{3} / \mathrm{min}$ unless stated otherwise. The products of the reaction and the unreacted substrates were analysed using the Agilent $6890 \mathrm{~N}$ gas chromatograph (Agilent Technology, Santa Clara, CA, USA) equipped with two columns (molecular sieve 5A for the analysis of $\mathrm{N}_{2}, \mathrm{CO}$ and $\mathrm{O}_{2}$ and Hayesep $\mathrm{Q}$ for the analysis of $\mathrm{H}_{2}, \mathrm{CO}_{2}$, and hydrocarbons) and TCD.

The conversion of methane $\left(\mathrm{X}_{\mathrm{CH}_{4}}\right)$ and selectivity to $\mathrm{C}_{2+}\left(S_{\mathrm{C}_{2+}}\right)$ were calculated according to the following formulas:

$$
\begin{aligned}
X_{\mathrm{CH}_{4}} & =\frac{n_{(\text {inlet }) \mathrm{CH}_{4}}-n_{(\text {outlet }) \mathrm{CH}_{4}}}{n_{(\text {inlet }) \mathrm{CH}_{4}}} \cdot 100 \% \\
S_{\mathrm{C}_{2+}} & =\frac{\sum a_{i} \cdot n_{i}}{n_{(\text {inlet }) \mathrm{CH}_{4}}-n_{(\text {outlet }) \mathrm{CH}_{4}}} \cdot 100 \%
\end{aligned}
$$


where: $n_{\text {(inlet) } \mathrm{CH}_{4}}$ and $n_{\text {(outlet) } \mathrm{CH}_{4}}$ are numbers of methane moles in the inlet and outlet of the reactor, respectively; $n_{i}$ is a number of moles of the $i$-th product in the outlet and $a_{i}$ is a number of carbon atoms in the " $i$ " product (ethane, ethene, propane and propene).

Carbon balance in the catalytic tests was above $95 \%$.

\section{Conclusions}

Unpurified biogas originating from two different raw materials was used as a feedstock in the oxidative coupling of methane. For comparison, a pure methane-based feedstock was investigated as well. The physicochemical analysis reveals small differences in the phase and chemical composition of $\mathrm{Mn}-\mathrm{Na}_{2} \mathrm{WO}_{4} / \mathrm{SiO}_{2}$ after the OCM process in which unpurified biogas and pure methane were applied. The surface concentration of $\mathrm{Na}, \mathrm{W}$ and $\mathrm{O}$ in $\left(\mathrm{MO}_{\mathrm{x}}\right)$ on the $\mathrm{Mn}-\mathrm{Na}_{2} \mathrm{WO}_{4} / \mathrm{SiO}_{2}$ catalyst was lower when biogas 1 or biogas 2 were used as a feedstock. Moreover, XPS study revealed the absence of sulphur on the surface of used catalysts in the OCM process with both biogases. This indicates that under OCM conditions, sulphur-containing compounds from both studied unpurified biogas did not poisoning catalyst.

The catalytic investigation has revealed that the type of feedstock used as the source of methane has a relatively small influence on the conversion of methane. The differences in methane conversion between all tested feedstock was below 3\%. On the other hand, a more significant difference was observed in selectivity to $\mathrm{C}_{2}$. Depending on the feedstock, the differences in selectivity to $\mathrm{C}_{2}$ reaches $9 \%$. Moreover, it was found that the $\mathrm{CO}_{2}$ that is one of the main components of biogas has influence on catalytic performance in the OCM process. The appropriate selection of process conditions, particularly the temperature (above $1073 \mathrm{~K}$ ) and the $\mathrm{CH}_{4} / \mathrm{O}_{2}$ molar ratio (above 3.8) in feedstock, allows for the directing of the process in such a way that the presence of $\mathrm{CO}_{2}$ has a beneficial effect on the $\mathrm{C}_{2}$ selectivity and, at the same time, does not reduce the methane conversion.

Supplementary Materials: The following supporting information can be downloaded at: https: / / www.mdpi.com/article/10.3390/catal12010054/s1, Figure S1: (a) Variation of methane conversion andvselectivity to $\mathrm{C}_{2+}$ with partial pressure of $\mathrm{CO}_{2}$ over $\mathrm{Mn}-\mathrm{Na}_{2} \mathrm{WO}_{4} / \mathrm{SiO}_{2}$ catalyst. Figure S2: Variation of conversion of $\mathrm{CH} 4$ and selectivity to $\mathrm{C}_{2+}$ with time-on-stream during repeatable switching on $\mathrm{CO}_{2}$ during OCM process over the $\mathrm{Mn}-\mathrm{Na}_{2} \mathrm{WO}_{4} / \mathrm{SiO}_{2}$ catalyst. Figure S3: Variation of methane conversion and selectivity to $\mathrm{C}_{2+}$ with temperature in the OCM process carried out with and without $\mathrm{CO}_{2}$ over $\mathrm{Mn}-\mathrm{Na}_{2} \mathrm{WO}_{4} / \mathrm{SiO}_{2}$ catalyst.

Author Contributions: Conceptualization, B.M., B.K.-Ł. and I.C.; methodology, B.M. and J.S.; validation, B.M., J.S. and D.G.; formal analysis, B.M., B.K.-Ł. and I.C.; investigation, B.M., J.S. and D.G.; resources, J.S.; data curation, B.M.; writing-original draft preparation, B.M.; writing-review and editing, B.M. and I.C.; visualization, B.M.; supervision, I.C. and B.K.-Ł. All authors have read and agreed to the published version of the manuscript.

Funding: This research received no external funding.

Conflicts of Interest: The authors declare no conflict of interest.

\section{References}

1. Ali, M.M.; Ndongo, M.; Bilal, B.; Yetilmezsoy, K.; Youm, I.; Bahramian, M. Mapping of biogas production potential from livestock manures and slaughterhouse waste: A case study for African countries. J. Clean. Prod. 2020, 256, 120499. [CrossRef]

2. Kazimierowicz, A.; Dzienis, L.; Dębowski, M.; Zieliński, M. Optimisation of methane fermentation as a valorisation method for food waste products. Biomass Bioenergy 2021, 144, 105913. [CrossRef]

3. Otero, A.; Mendoza, M.; Carreras, R.; Fernandez, B. Biogas production from slaughterhouse waste: Effect of blood content and fat saponification. Waste Manag. 2021, 133, 119-126. [CrossRef]

4. Kazimierowicz, J.; Bartkowska, I.; Walery, M. Effect of Low-Temperature Conditioning of Excess Dairy Sewage Sludge with the Use of Solidified Carbon Dioxide on the Efficiency of Methane Fermentation. Energies 2021, 14, 150. [CrossRef]

5. Kazimierowicz, J.; Dzienis, L. Giant Miscanthus as a Substrate for Biogas Production. J. Ecol. Eng. 2015, 16, 139-142. [CrossRef]

6. Yang, Q.; Wu, B.; Yao, F.; He, L.; Chen, F.; Ma, Y.; Shu, X.; Hou, K.; Wang, D.; Li, X. Biogas production from anaerobic co-digestion of waste activated sludge: Co-substrates and influencing parameters. Rev. Environ. Sci. Biotechnol. 2019, 18, 771-793. [CrossRef] 
7. $\quad$ Bücker, F.; Marder, M.; Peiter, M.R.; Neutzling Lehn, D.; Mendonça Esquerdo, V.; de Almeida Pinto, L.A.; Konrad, O. Fish waste: An efficient alternative to biogas and methane production in an anaerobic mono-digestion system. Renew. Energy 2020, 147, 798-805. [CrossRef]

8. Rasi, S.; Läntelä, J.; Rintala, J. Trace compounds affecting biogas energy utilisation-A review. Energy Convers. Manag. 2011, 52, 3369-3375. [CrossRef]

9. Li, Y.; Alaimo, C.P.; Kim, M.; Kado, N.Y.; Peppers, J.; Xue, J.; Wan, C.; Green, P.G.; Zhang, R.; Jenkins, B.M.; et al. Composition and Toxicity of Biogas Produced from Different Feedstocks in California. Environ. Sci. Technol. 2019, 53, 11569-11579. [CrossRef]

10. Calbry-Muzyka, A.; Madi, H.; Rüsch-Pfund, F.; Gandiglio, M.; Biollaz, S. Biogas composition from agricultural sources and organic fraction of municipal solid waste. Renew. Energy 2022, 181, 1000-1007. [CrossRef]

11. Yang, L.; Ge, X.; Wan, C.; Yu, F.; Li, Y. Progress and perspectives in converting biogas to transportation fuels. Renew. Sust. Energ. Rev. 2014, 40, 1133-1152. [CrossRef]

12. Calbry-Muzyka, A.S.; Schildhauer, T.J. Direct Methanation of Biogas-Technical Challenges and Recent Progress. Front. Energy Res. 2020, 8, 570887. [CrossRef]

13. Dannesboe, C.; Bøgild Hansen, J.; Johannsen, I. Catalytic methanation of $\mathrm{CO}_{2}$ in biogas: Experimental results from a reactor at full scale. React. Chem. Eng. 2020, 5, 183-189. [CrossRef]

14. Han, D.; Kim, Y.; Byun, H.; Cho, W.; Baek, Y. $\mathrm{CO}_{2}$ Methanation of Biogas over $20 \mathrm{wt} \%$ Ni-Mg-Al Catalyst: On the Effect of N $\mathrm{CH}_{4}$, and $\mathrm{O}_{2}$ on $\mathrm{CO}_{2}$ Conversion Rate. Catalysts 2020, 10, 1201. [CrossRef]

15. Baena-Moreno, F.M.; Sebastia-Saez, D.; Wang, Q.; Reina, T.R. Is the production of biofuels and bio-chemicals always profitable? Co-production of biomethane and urea from biogas as case study. Energy Convers. Manag. 2020, 220, 113058. [CrossRef]

16. Nahar, G.; Mote, D.; Dupont, V. Hydrogen production from reforming of biogas: Review of technological advances and an Indian perspective. Renew. Sust. Energ. Rev. 2017, 76, 1032-1052. [CrossRef]

17. Minutillo, M.; Perna, A.; Sorce, A. Green hydrogen production plants via biogas steam and autothermal reforming processes: Energy and exergy analyses. Appl. Energy 2020, 277, 115452. [CrossRef]

18. Renda, S.; Ricca, A.; Palma, V. Coke-Resistant Rh and Ni Catalysts Supported on $\gamma-\mathrm{Al}_{2} \mathrm{O}_{3}$ and $\mathrm{CeO}_{2}$ for Biogas Oxidative Steam Reforming. Chem. Proc. 2020, 2, 10.

19. Zhumabek, M.; Xanthopoulou, G.; Tungatarova, S.A.; Baizhumanova, T.S.; Vekinis, G.; Murzin, D.Y. Biogas Reforming over Al-Co Catalyst Prepared by Solution Combustion Synthesis Method. Catalysts 2021, 11, 274. [CrossRef]

20. Goula, M.A.; Charisiou, N.D.; Siakavelas, G.; Tzounis, L.; Tsiaoussis, I.; Panagiotopoulou, P.; Goula, G.; Yentekakis, I.V. Syngas production via the biogas dry reforming reaction over Ni supported on zirconia modified with $\mathrm{CeO}_{2}$ or $\mathrm{La}_{2} \mathrm{O}_{3}$ catalysts. Int. J. Hydrog. Energy 2017, 42, 13724-13740. [CrossRef]

21. Moral, A.; Reyero, I.; Alfaro, C.; Bimbela, F.; Gandía, L.M. Syngas production by means of biogas catalytic partial oxidation and dry reforming using Rh-based catalysts. Catal. Today 2018, 299, 280-288. [CrossRef]

22. Habibi, N.; Wang, Y.; Arandiyan, H.; Rezaei, M. Effect of substitution by $\mathrm{Ni}$ in $\mathrm{MgAl}_{2} \mathrm{O}_{4}$ spinel for biogas dry reforming. Int. J. Hydrog. Energy 2017, 42, 24159-24168. [CrossRef]

23. Madeira, J.G.F.; Boloy, R.A.M.; Delgado, A.R.S.; Lima, F.R.; Coutinho, E.R.; de Castro Pereira Filho, R. Ecological analysis of hydrogen production via biogas steam reforming from cassava flour processing wastewater. J. Clean. Prod. 2017, 162, 709-716. [CrossRef]

24. Yao, J.; Kraussler, M.; Benedikt, F.; Hofbauer, H. Techno-economic assessment of hydrogen production based on dual fluidized bed biomass steam gasification, biogas steam reforming, and alkaline water electrolysis processes. Energy Convers. Manag. 2017, 145, 278-292. [CrossRef]

25. Zeng, Y.X.; Wang, L.; Wuc, C.F.; Wang, J.Q.; Shen, B.X.; Tu, X. Low temperature reforming of biogas over K-, Mg- and Ce-promoted $\mathrm{Ni} / \mathrm{Al}_{2} \mathrm{O}_{3}$ catalysts for the production of hydrogen rich syngas: Understanding the plasma-catalytic synergy. Appl. Catal. B 2018, 224, 469-478. [CrossRef]

26. Kan, X.; Zhou, D.; Yang, W.; Zhai, X.; Wang, C.H. An investigation on utilization of biogas and syngas produced from biomass waste in premixed spark ignition engine. Appl. Energy 2018, 212, 210-222. [CrossRef]

27. Chiodo, V.; Maisano, S.; Zafarana, G.; Urbani, F. Effect of pollutants on biogas steam reforming. Int. J. Hydrog. Energy 2017, 42, 1622-1628. [CrossRef]

28. Gao, Y.; Jiang, J.; Meng, Y.; Yan, F.; Aihemaiti, A. A review of recent developments in hydrogen production via biogas dry Reforming. Energy Convers. Manag. 2018, 171, 133-155. [CrossRef]

29. Elsayed, N.H.; Elwell, A.; Joseph, B.; Kuhn, J.N. Effect of silicon poisoning on catalytic dry reforming of simulated biogas. Appl. Catal. A Gen. 2017, 538, 157-164. [CrossRef]

30. Chein, R.; Yang, Z.W. $\mathrm{H}_{2} \mathrm{~S}$ effect on dry reforming of biogas for syngas production. Int. J. Energy Res. 2019, 43, 3330-3345. [CrossRef]

31. Gunnerman, R.W.; Gunnerman, P.W. Process for Conversion of Biogas to Liquid Fuels. U.S. Patent 20110000128A1, 6 January 2011.

32. Ge, X.; Yang, L.; Sheets, J.P.; Yu, Z.; Li, Y. Biological conversion of methane to liquid fuels: Status and opportunities. Biotechnol. Adv. 2014, 32, 1460-1475. [CrossRef]

33. Patel, S.K.S.; Mardina, P.; Kim, D.; Kim, S.Y.; Kalia, V.C.; Kim, I.W.; Lee, J.K. Improvement in methanol production by regulating the composition of synthetic gas mixture and raw biogas. Bioresour. Technol. 2016, 218, 202-208. [CrossRef] 
34. Sheets, J.P.; Ge, X.; Li, Y.F.; Yu, Z.; Li, Y. Biological conversion of biogas to methanol using methanotrophs isolated from solid-state anaerobic digestate. Bioresour. Technol. 2016, 201, 50-57. [CrossRef]

35. Abatzoglou, N.; Boivin, S. A review of biogas purification Processes. Biofuels Bioprod. Bioref. 2009, 3, 42-71. [CrossRef]

36. Miltner, M.; Makaruk, A.; Harasek, M. Review on available biogas upgrading technologies and innovations towards advanced solutions. J. Clean. Prod. 2017, 161, 1329-1337. [CrossRef]

37. Angelidaki, I.; Treu, L.; Tsapekos, P.; Luo, G.; Campanaro, S.; Wenzel, H.; Kougias, P.G. Biogas upgrading and utilization: Current status and perspectives. Biotechnol. Adv. 2018, 36, 452-466. [CrossRef]

38. Kapoor, R.; Ghosh, P.; Tyagi, B.; Vijay, V.K.; Vijay, V.; Thakur, I.S.; Kamyab, H.; Nguyen, D.D.; Kumar, A. Advances in biogas valorization and utilization and utilization system: A comprehensive review. J. Clean. Prod. 2020, 273, 123052. [CrossRef]

39. Adnan, A.I.; Ong, M.Y.; Nomanbhay, S.; Chew, K.W.; Show, P.L. Technologies for Biogas Upgrading to Biomethane: A Review. Bioengineering 2019, 6, 92. [CrossRef]

40. Budzianowski, W.M. A review of potential innovations for production, conditioning and utilization of biogas with multiplecriteria assessment. Renew. Sust. Energ. Rev. 2016, 54, 1148-1171. [CrossRef]

41. Khan, I.U.; Othman, M.H.D.; Hashim, H.; Matsuura, T.; Ismail, A.F.; Rezaei-Dasht Arzhandi, M.; Azelee, I.W. Biogas as a renewable energy fuel-A review of biogas upgrading, utilisation and storage. Energy Convers. Manag. 2017, 150, 277-294. [CrossRef]

42. Sun, Q.; Li, H.; Yan, J.; Liu, L.; Yu, Z.; Yu, X. Selection of appropriate biogas upgrading technology-A review of biogas cleaning, upgrading and utilisation. Renew. Sust. Energ. Rev. 2015, 51, 521-532. [CrossRef]

43. Awe, O.W.; Zhao, Y.; Nzihou, A.; Minh, D.P.; Lyczko, N. A Review of Biogas Utilisation, Purification and Upgrading Technologies. Waste Biomass Valor. 2017, 8, 267-283. [CrossRef]

44. Scarlat, N.; Dallemand, J.-F.; Fahl, F. Biogas: Developments and perspectives in Europe. Renew. Energy 2018,129 , 457-472. [CrossRef]

45. Yentekakis, I.V.; Goula, G. Biogas Management: Advanced Utilization for Production of Renewable Energy and Added-value Chemicals. Front. Environ. Sci. 2017, 5, 7. [CrossRef]

46. Abanades, S.; Abbaspour, H.; Ahmadi, A.; Das, B.; Ehyaei, M.A.; Esmaeilion, F.; Assad, M.E.H.; Hajilounezhad, T.; Jamali, D.H.; Hmida, A.; et al. A critical review of biogas production and usage with legislations framework across the globe. Int. J. Environ. Sci. Technol. 2021, 1-24. [CrossRef]

47. Penteado, A.T.; Kim, M.; Godini, H.R.; Esche, E.; Repke, J.-U. Biogas as a Renewable Feedstock for Green Ethylene Production via Oxidative Coupling of Methane: Preliminary Feasibility Study. Chem. Eng. Trans. 2017, 61, 589-594.

48. Penteado, A.T.; Kim, M.; Godini, H.R.; Esche, E.; Repke, J.-U. Techno-economic evaluation of a biogas-based oxidative coupling of methane process for ethylene production. Front. Chem. Sci. Eng. 2018, 12, 598-618.

49. Gu, S.; Choi, J.-W.; Suh, D.J.; Park, Y.-K.; Choi, J.; Ha, J.-M. Upgrading of sulfur-containing biogas into high quality fuel via oxidative coupling of methane. Int. J. Energy Res. 2021, 45, 19363-19377. [CrossRef]

50. Sokolov, S.; Seeburg, D.; Wohlrab, S.; Friedel, M.; Nitzsche, J.; Kondratenko, E.V. An Approach Using Oxidative Coupling of Methane for Converting Biogas and Acid Natural Gas into High-Calorific Fuels. Ind. Eng. Chem. Res. 2019, 58, 2454-2459. [CrossRef]

51. Pak, S.; Lunsford, J. Thermal effects during the oxidative coupling of methane over $\mathrm{Mn} / \mathrm{Na}_{2} \mathrm{WO} 4 / \mathrm{SiO} 2$ and $\mathrm{Mn} / \mathrm{Na}_{2} \mathrm{WO} 4 / \mathrm{MgO}$ catalysts. Appl. Catal. A Gen. 1998, 168, 131-137. [CrossRef]

52. Michorczyk, B.; Ogonowski, J.; Michorczyk, P. Oxidative coupling of methane in the presence of various gaseous additives Przemyst. Chem. 2015, 94, 572-576.

53. Takanabe, K.; Iglesia, E. Rate and Selectivity Enhancements Mediated by OH Radicals in the Oxidative Coupling of Methane Catalyzed by Mn/ $\mathrm{Na}_{2} \mathrm{WO}_{4} / \mathrm{SiO}_{2}$. Angew. Chem. Int. Ed. 2008, 47, 7689-7693. [CrossRef]

54. Takanabe, K.; Iglesia, E. Mechanistic Aspects and Reaction Pathways for Oxidative Coupling of $\mathrm{Methane}$ on $\mathrm{Mn}_{\mathbf{N}} \mathrm{Na} \mathrm{WO}_{4} / \mathrm{SiO} 2$ Catalysts. J. Phys. Chem. C 2009, 113, 10131-10145. [CrossRef]

55. Shi, J.; Yao, L.; Hu, C. Effect of $\mathrm{CO}_{2}$ on the structural variation of $\mathrm{Na}_{2} \mathrm{WO}_{4} / \mathrm{Mn} / \mathrm{SiO} 2$ catalyst for oxidative coupling of methane to ethylene. J. Energy Chem. 2015, 24, 394-400. [CrossRef]

56. Jiang, Z.C.; Yu, C.J.; Fang, X.P.; Li, S.B.; Wang, H.L. Oxide/Support Interaction and Surface Reconstruction in the $\mathrm{Na}_{2} \mathrm{WO}_{4} / \mathrm{SiO}_{2}$ System. J. Phys. Chem. 1993, 97, 12870-12875. [CrossRef]

57. Palermo, A.; Vazquezy, J.P.H.; Lee, A.F.; Tikhov, M.S.; Lambert, R.M. Critical influence of the amorphous silica-to-cristobalite phase transition on the performance of $\mathrm{Mn} / \mathrm{Na}_{2} \mathrm{WO}_{4} / \mathrm{SiO}_{2}$ catalysts for the oxidative coupling of methane. J. Catal. 1998, 177, 259-266. [CrossRef]

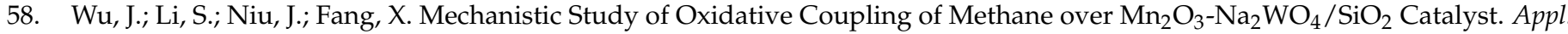
Catal. A Gen. 1995, 124, 9-18. [CrossRef]

59. Chua, Y.; Mohamed, A.; Bhatia, S. Oxidative coupling of methane for the production of ethylene over sodium-tungsten-manganesesupported-silica catalyst (Na-W-Mn/SiO $)$. Appl. Catal. A Gen. 2008, 343, 142-148. [CrossRef]

60. Zhang, H.; Wu, J.; Qin, S.; Hu, C. Study of the effect of gas space time on the combination of methane gas-phase oxidation and catalytic oxidative coupling over $\mathrm{Mn} / \mathrm{Na}_{2} \mathrm{WO}_{4} / \mathrm{SiO}_{2}$ catalyst. Ind. Eng. Chem. Res. 2006, 45, 7090-7095. [CrossRef]

61. Yan, Q.; Wang, Y.; Jin, Y.; Chen, Y. Methane oxidative coupling over $\mathrm{Na}_{2} \mathrm{WO}_{4} / \mathrm{SiO}_{2}$. Catal. Lett. 1992, 13, 221-228. [CrossRef] 
62. Fleischer, V.; Simon, U.; Parishan, S.; Colmenares, M.G.; Görke, O.; Gurlo, A.; Riedel, W.; Thum, L.; Schmidt, J.; Risse, T.; et al. Investigation of the role of the $\mathrm{Na}_{2} \mathrm{WO}_{4} / \mathrm{Mn} / \mathrm{SiO}_{2}$ catalyst composition in the oxidative coupling of methane by chemical looping experiments. J. Catal. 2018, 360, 102-117. [CrossRef]

63. Wang, D.; Xu, M.; Shi, C.; Lunsford, J.H. Effect of carbon dioxide on the selectivities obtained during the partial oxidation of methane and ethane over $\mathrm{Li}^{+} / \mathrm{MgO}$ catalysts. Catal. Lett. 1993, 18, 323-328. [CrossRef]

64. Aika, K.; Nishiyama, T. Utilisation of $\mathrm{CO}_{2}$ in the oxidative coupling of methane over PbO-MgO and PbO-CaO. Chem. Commun. 1988, 1, 70-71. [CrossRef]

65. Thien, C.Y.; Mohamed, A.R.; Bhatia, S. Process optimization of oxidative coupling of methane for ethylene production using response surface methodology. J. Chem. Technol. Biotechnol. 2007, 82, 81-91. [CrossRef]

66. Ehsani, M.R.; Bateni, H.; Parchikolaei, G.R. Modeling the oxidative coupling of methane using artificial neural network and optimizing of its operational conditions using genetic algorithm. Korean J. Chem. Eng. 2012, 29, 855-861. [CrossRef]

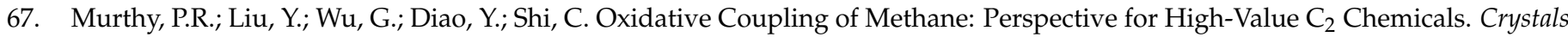
2021, 11, 1011-1030. [CrossRef]

68. Yoon, S.; Lim, S.; Choi, J.-W.; Suh, D.J.; Song, K.H.; Ha, J.-M. Study on the unsteady state oxidative coupling of methane: Effects of oxygen species from $\mathrm{O}_{2}$, surface lattice oxygen, and $\mathrm{CO}_{2}$ on the $\mathrm{C}_{2+}$ selectivity. RSC Adv. 2020, 10, 35889-35897. [CrossRef]

69. Papa, F.; Gingasu, D.; Patron, L.; Miyazaki, A.; Balint, I. On the nature of active sites and catalytic activity for OCM reaction of alkaline-earth oxides-neodymia catalytic systems. Appl. Catal. A Gen. 2010, 375, 172-178. [CrossRef]

70. Suzuki, T.; Wada, K.; Watanabe, Y. Effects of carbon dioxide and catalyst preparation on the oxidative dimerization of methane. Appl. Catal. A Gen. 1990, 59, 213-225. [CrossRef]

71. Dissanayake, D.; Lunsford, J.H.; Rosynek, M.P. Oxidative coupling of methane over oxide-supported barium catalysts. J. Catal. 1993, 143, 286-298. [CrossRef]

72. Korf, S.J.; Roos, J.A.; de Bruijn, N.A.; van Ommen, J.G.; Ross, J.R.H. Influence of $\mathrm{CO}_{2}$ on the oxidative coupling of methane over a lithium promoted magnesium oxide catalyst. Chem. Commun. 1987, 19, 1433-1434. [CrossRef]

73. Wang, D.; Rosynek, M.P.; Lunsford, J.H. Oxidative coupling of methane over oxide-supported sodium-manganese catalysts. J. Catal. 1995, 155, 390-402. [CrossRef]

74. Pak, S.; Qiu, P.; Lunsford, J.H. Elementary Reactions in the Oxidative Coupling of Methane over $\mathrm{Mn} / \mathrm{Na}_{2} \mathrm{WO}_{4} / \mathrm{SiO}_{2}$ and $\mathrm{Mn} / \mathrm{Na}_{2} \mathrm{WO}_{4} / \mathrm{MgO}$ Catalysts. J. Catal. 1998, 179, 222-230. [CrossRef]

75. Daneshpayeh, M.; Khodadadi, A.; Mostoufi, N.; Mortazavi, Y.; Sotudeh-Gharebagh, R.; Talebizadeh, A. Kinetic modeling of oxidative coupling of methane over $\mathrm{Mn} / \mathrm{Na}_{2} \mathrm{WO}_{4} / \mathrm{SiO}_{2}$ catalyst. Fuel Process. Technol. 2009, 90, 403-410. [CrossRef]

76. Bogdan, B.; Michorczyk, B.; Rokicińska, A.; Basta, M.; Myradova, M.; Kuśtrowski, P.; Michorczyk, P. Monolithic composites with geometry controlled by polymeric 3D printed templates: Characterization and catalytic performance in OCM. Appl. Surf. Sci. 2021, 553, 149554. [CrossRef]

77. Michorczyk, P.; Hędrzak, E.; Węgrzyniak, A. Preparation of monolithic catalysts using 3D printed templates for oxidative coupling of methane. J. Mater. Chem. A 2016, 4, 18753-18756. [CrossRef]

78. Sikora, J.; Mruk, B. Quantitative and qualitative analysis of biogas emitted from batches composed on the basis of available factions on the farm. Infrastruct. Ecol. Rural. Areas 2016, 3, 907-917.

79. Sikora, J.; Niemiec, M.; Szelag-Sikora, A.; Kuboń, M.; Olech, E.; Marczuk, A. Biogasification of wastes from industrial processing of carps. Przemyst. Chem. 2017, 96, 2275-2278. 